\title{
ANTIOXIDANTS IN THE CONTROL OF MICROORGANISM CONTAMINATION AND PHENOL OXIDATION IN Eugenia pyriformis
}

\author{
ANTIOXIDANTES NO CONTROLE DA CONTAMINAÇÃO MICROBIANA E \\ DA OXIDAÇÃO FENÓLICA EM Eugenia pyriformis
}

\section{Franscinely Aparecida de ASSIS ${ }^{1}$; Filipe Almendagna RODRIGUES ${ }^{2}$; Moacir PASQUAL $^{3}$; Gleice Aparecida de ASSIS ${ }^{4}$; José Magno Queiroz LUZ ${ }^{5}$; Fabio JANONI ${ }^{6}$; Irton de Jesus Silva COSTA ${ }^{7}$; Bárbara Nogueira Souza COSTA ${ }^{8}$; Joyce Dória Rodrigues SOARES ${ }^{9}$}

1. Professora efetiva do Centro Universitário de Goiatuba (UNICERRADO), Goiatuba, GO, Brasil. franscinelyagronomia@yahoo.com.br; 2. Pós-doutorando em Agronomia/Fitotecnia, DAG /UFLA, Lavras, MG, Brasil; 3. Professor titular do DAG/ UFLA, Lavras, MG, Brasil; 4. Professora adjunta da Universidade Federal de Uberlândia (UFU), Campus Monte Carmelo, Monte Carmelo, MG, Brasil; 5. Professor titular da UFU, Instituto de Ciências Agrárias, Campus Umuarama, MG, Brasil; 6. Engenheiro Agrônomo da (UFU), Campus Monte Carmelo, Monte Carmelo, MG, Brasil; 7. Doutor em Agronomia/Fitotecnia, Lavras, Minas Gerais, MG, Brasil; 8. Doutoranda do DAG/UFLA, Lavras, Minas Gerais, MG, Brasil; 9. Professora adjunta do DAG/ UFLA, Lavras, MG, Brasil.

\begin{abstract}
Uvaia (Eugenia pyriformis) is a fruit tree of the Myrtaceae family. It has recalcitrant seeds of limited longevity, making seed propagation difficult. Micropropagation is an alternative method to obtain a large quantity of progeny plants in a short period of time, by using any part of the plant as explant. The high concentration of phenols associated with the chemical composition of the Myrtaceae, and the presence of microorganisms in the plant material or culture media, can make in vitro propagation difficult and/or impossible. The objective was to evaluate various concentrations of antioxidants affecting the control of microbial contamination and phenol oxidation in vitro in uvaia. A completely randomized design was used, with a 3 (antioxidants PVP, L-cysteine, and ascorbic acid) $\times 3$ (antioxidant concentrations 100, 200, and $\left.300 \mathrm{mg} \mathrm{L}^{-1}\right) \times 2$ (activated charcoal at 0 and $2 \mathrm{~g} \mathrm{~L}^{-1}$ ) factorial arrangement +2 additional variables (absence of antioxidants and activated charcoal; absence of antioxidants with $2 \mathrm{~g} \mathrm{~L}^{-1}$ activated charcoal), with three repetitions comprising four plants each. The percentage of bacterial and fungal contaminations, along with the number of oxidized explants, was evaluated after 7, 14 and 21 days of in vitro cultivation. It was concluded that, where bacterial and fungal contaminations were concerned, in vitro cultivation of uvaia can be performed without the use of antioxidants. PVP or ascorbic acid must, however be used in the process, at a concentration of $300 \mathrm{mg} \mathrm{L}^{-1}$, along with $2 \mathrm{~g}$ $\mathrm{L}^{-1}$ of activated charcoal. This helps to minimize phenol oxidation.
\end{abstract}

KEYWORDS: Ascorbic acid. Activated charcoal. L-cysteine. Polyvinylpyrrolidone, Uvaia.

\section{INTRODUCTION}

Eugenia pyriformis (Cambess.), known commonly as "uvaia", is a perennial fruit tree of the Myrtaceae family. It is prized for its fleshy and velvety fruits, the pulp of which is rich in antioxidants and vitamin $\mathrm{C}$, thus contributing to its inclusion in diets (SILVA et al., 2014). Seed propagation is, however, difficult owing to the short natural longevity of the seeds, together with the recalcitrant behavioral characteristics of the species (SCALON et al., 2012), which instigated the research on other propagation methods.

Micropropagation is a viable alternative, since it allows for a large quantity of healthy progeny plants to be obtained in a short period of time and because any part of the plant can be used as explant (NASCIMENTO et al., 2008; GARCÍAGONZALES et al., 2010).
Micropropagation protocols are already defined for a great diversity of plant species, from fruit species (RODRIGUES et al., 2013) to medicinal plants (MORAIS et al., 2012), which ensures the sustainable exploitation of species and allows increasing the supply of compounds biologically active, decreasing the price of phytochemical active ingredients derived from medicinal plants (PLETSCH, 1998). Through this technique it is also possible to produce secondary metabolites in vitro, thus ensuring alternative forms of exploitation, especially in endangered ecosystems.

The in vitro establishment phase is considered the most difficult, since the success of subsequent procedures, such as multiplication and acclimatization, depends on the morphophysiological and phytosanitary state of the explants maintained in the growth media (NASCIMENTO et al., 2008; PINHAL et al., 2011). 
A serious problem associated with micropropagation is contamination by microorganisms (bacteria and fungal). These agents establish themselves in the growth media and/or plant material and may lead to the death of the explants by lowering the $\mathrm{pH}$ of the media, by the production of toxic metabolites or via competition for nutrients (SOUSA et al., 2007; LEONE et al., 2016).

During the in vitro establishment phase there is also a need to control oxidation caused by phenolic exudation at the sites where the explants were cut, which are responsible for darkening the explants via the activity of peroxidase enzymes (LAUKKANEN et al., 2000) and polyphenol oxidase (WILLADINO et al., 2013).

Uvaia, like other Myrtaceae, has a high concentration of phenolic acids in its chemical composition (HAMINIUK et al., 2014). Phenols and other exudates in in vitro cultivation systems can compromise the micropropagation process, since they inhibit the initial growth of the explants, which may lead to its death (BASSAN et al., 2006). The concentration of such compounds is related to the type of explant used, with nodal segments usually presenting lower concentrations than do apical segments (GOLLE et al., 2012), which justifies the addition of antioxidant substances to the culture media.

Research is currently being developed regarding the effects of antioxidants PVP, Lcysteine, ascorbic acid and activated charcoal on guava (Psidium guajava Linnaeus) (AGUILAR et al., 2016), lupin (Lupinus mutabilis Sweet) (MAMANI et al., 2014), 'alecrim-de-tabuleiro' (Lippia gracilis Schauer) (MARINHO et al., 2011), 'jacarandá da Bahia' Dalbergia nigra (Vell.) Allemao ex Benth. (SARTOR et al., 2013) respectively, in addition to other species, with the aim of controlling oxidative processes during micropropagation. These substances are effective in the antioxidant action and their cost is relatively smaller when compared to other substances, of equal action, available in the biotechnology market. In this way, the aim of the present research was to explore, besides the antioxidant potential, the antimicrobial action, because there is no reports in the literature on the action of these substances as antimicrobial/antioxidant agents in E. pyriformis, which highlights the relevance of the present study for the micropropagation of this fruit tree.

The aim of this study was, therefore, to evaluate the types and concentrations of antioxidants that control microbial contamination and phenol oxidation in vitro in E. pyriformis.

\section{MATERIAL AND METHODS}

Nodal segments of E. pyriformis removed from adult plants were used as explants. The plants were previously sprayed with the antibiotic penicillin $\left(1 \mathrm{~g} \mathrm{~L}^{-1}\right)$, three times per week, for a period of four weeks. In the second week, the systemic fungicide Cerconil $\mathrm{WP}^{\circledR}$ (thiophanatemethyl and chlorothalonil) (Iharabras S.A. Chemical Industries, Sorocaba, São Paulo, Brazil) was added to the pulverizations at a concentration of $2 \mathrm{~g}$ of commercial product per liter of water (adapted from RAMOS et al., 2013).

After the pulverizations, the young nodal segments were collected and taken to the Plant Tissue Culture Laboratory, Department of Agriculture, Federal University of Lavras (UFLA), Lavras, Minas Gerais, Brazil. Where they were washed with a neutral detergent and rinsed for 5 minutes in running water. The explants were then disinfected using a 70\% alcohol solution with Tween 20 (one drop per $100 \mathrm{~mL}$ ) for 90 seconds and immersed in a solution of sodium hypochlorite (1\% active chlorine) for a period of 20 minutes. The explants were subsequently subjected to a triple wash in autoclaved distilled water inside a laminar flow cabinet.

Test tubes $(20 \times 150 \mathrm{~mm})$ containing $15 \mathrm{~mL}$ of Murashige and Skoog (MS) culture medium, comprised of salts and vitamins (MURASHIGE and SKOOG, 1962), and with the addition of $30 \mathrm{~g} \mathrm{~L}^{-1}$ of sucrose and $5.5 \mathrm{~g} \mathrm{~L}^{-1}$ of agar, were used in this study. The $\mathrm{pH}$ was adjusted to 5.8 and the medium autoclaved at $121^{\circ} \mathrm{C}$ and 1.2 atm for 20 minutes.

Methodology described by Golle et al. (2013) was used for inoculation in vitro, with the removal of existing leaf remains in each explant, each composed of two buds. In addition, the basal cut was performed at a slant, to increase contact surface area with the nutrient medium. All test tubes were kept in the dark in a plant growing room at a temperature of $25 \pm 2{ }^{\circ} \mathrm{C}$ for the duration of the study so as to minimize the effects of oxidation.

Evaluations were performed on days 7, 14 and 21 following in vitro cultivation, measuring the percentage of bacterial (presence of bacterial colonies near the explants) and fungal contamination (contamination formed of fungal mycelia near the explants), and phenol oxidation (explant darkening).

A completely randomized design was used, in a $3 \times 3 \times 2+2$ factorial trial, in which the factors were: antioxidants [(Polyvinylpyrrolidone (PVP), Lcysteine and ascorbic acid)], concentrations (100, 200 and $\left.300 \mathrm{mg} \mathrm{L}^{-1}\right)$, activated charcoal $(0$ and $2 \mathrm{~g}$ 
$\mathrm{L}^{-1}$ ) and additional factors (absence of antioxidants and activated charcoal; absence of antioxidants with $2 \mathrm{~g} \mathrm{~L}^{-1}$ activated charcoal), in a total of 20 treatments, with three repetitions of four explants, with one in each test tube.

The treatments were: $\mathrm{T} 1$ : absence of antioxidant and activated charcoal; $\mathrm{T} 2$ : absence of antioxidant and $2 \mathrm{~g} \mathrm{~L}^{-1}$ activated charcoal; T3: 100 $\mathrm{mg} \mathrm{L}^{-1}$ PVP and $0 \mathrm{~g} \mathrm{~L}^{-1}$ activated charcoal; T4: 100 $\mathrm{mg} \mathrm{L}^{-1}$ PVP and $2 \mathrm{~g} \mathrm{~L}^{-1}$ activated charcoal; T5: 200 $\mathrm{mg} \mathrm{L}{ }^{-1} \mathrm{PVP}$ and $0 \mathrm{~g} \mathrm{~L}^{-1}$ activated charcoal; T6: 200 $\mathrm{mg} \mathrm{L}^{-1}$ PVP and $2 \mathrm{~g} \mathrm{~L}^{-1}$ activated charcoal; T7: 300 $\mathrm{mg} \mathrm{L}^{-1} \mathrm{PVP}$ and $0 \mathrm{~g} \mathrm{~L}^{-1}$ activated charcoal; T8: 300 $\mathrm{mg} \mathrm{L}^{-1}$ PVP and $2 \mathrm{~g} \mathrm{~L}^{-1}$ activated charcoal; T9: 100 $\mathrm{mg} \mathrm{L}^{-1} \mathrm{~L}$-cysteine and $0 \mathrm{~g} \mathrm{~L}^{-1}$ activated charcoal; T10: $100 \mathrm{mg} \mathrm{L}^{-1} \mathrm{~L}$-cysteine and $2 \mathrm{~g} \mathrm{~L}^{-1}$ activated charcoal; T11: $200 \mathrm{mg} \mathrm{L}^{-1} \mathrm{~L}$-cysteine and $0 \mathrm{~g} \mathrm{~L}^{-1}$ activated charcoal; T12: $200 \mathrm{mg} \mathrm{L}^{-1} \mathrm{~L}$-cysteine and $2 \mathrm{~g} \mathrm{~L}^{-1}$ activated charcoal; T13: $300 \mathrm{mg} \mathrm{L}^{-1} \mathrm{~L}-$ cysteine and $0 \mathrm{~g} \mathrm{~L}^{-1}$ activated charcoal; T14: $300 \mathrm{mg}$ $\mathrm{L}^{-1} \mathrm{~L}$-cysteine and $2 \mathrm{~g} \mathrm{~L}^{-1}$ activated charcoal; T15: $100 \mathrm{mg} \mathrm{L}^{-1}$ ascorbic acid and $0 \mathrm{~g} \mathrm{~L}^{-1}$ activated charcoal; T16: $100 \mathrm{mg} \mathrm{L}^{-1}$ ascorbic acid and $2 \mathrm{~g} \mathrm{~L}^{-1}$ activated charcoal; T17: $200 \mathrm{mg} \mathrm{L}^{-1}$ ascorbic acid and $0 \mathrm{~g} \mathrm{~L}^{-1}$ activated charcoal; T18: $200 \mathrm{mg} \mathrm{L}^{-1}$ ascorbic acid and $2 \mathrm{~g} \mathrm{~L}^{-1}$ activated charcoal; T19: $300 \mathrm{mg} \mathrm{L}^{-1}$ ascorbic acid and $0 \mathrm{~g} \mathrm{~L}^{-1}$ activated charcoal; T20: $300 \mathrm{mg} \mathrm{L}^{-1}$ ascorbic acid and $2 \mathrm{~g} \mathrm{~L}^{-1}$ activated charcoal.

Data normality was analyzed using the Shapiro-Wilk test at the 5\% significance level. An analysis of variance was performed on the data using $\mathrm{R}^{\circledR}$ (R DEVELOPMENT CORE TEAM, 2014) statistics software, while the means were compared using Tukey's test with 5\% probability.

\section{RESULTS AND DISCUSSION}

All treatments were effective in controlling microbial activity (bacterial and fungal), with no contaminations seven days after inoculation. However, the following antioxidant treatments resulted in $50 \%$ or more of the uvaia explants being oxidized: PVP at all concentrations in the absence of activated charcoal (T3, T5 and T7); L-cysteine at the lowest and highest concentrations tested, in the absence (T9) and presence (T14) of activated charcoal, respectively; and ascorbic acid at the lowest concentration tested in the absence of activated charcoal (T15). No oxidation was observed in the T2, T4, T6 and T10 trials (Figure 1).

Fourteen days after inoculation, the explants exhibited similar behaviors to those observed at day 7 of bacterial and fungal contamination, except in $\mathrm{T} 1$ and T9 trials, where the absence of antioxidants (T1) or the use of $300 \mathrm{mg} \mathrm{L}^{-1}$ ascorbic acid (T19), both in the absence of activated charcoal, induced the appearance of bacterial colonies, even though they occurred in only $8.3 \%$ of the explants (Figure 2).

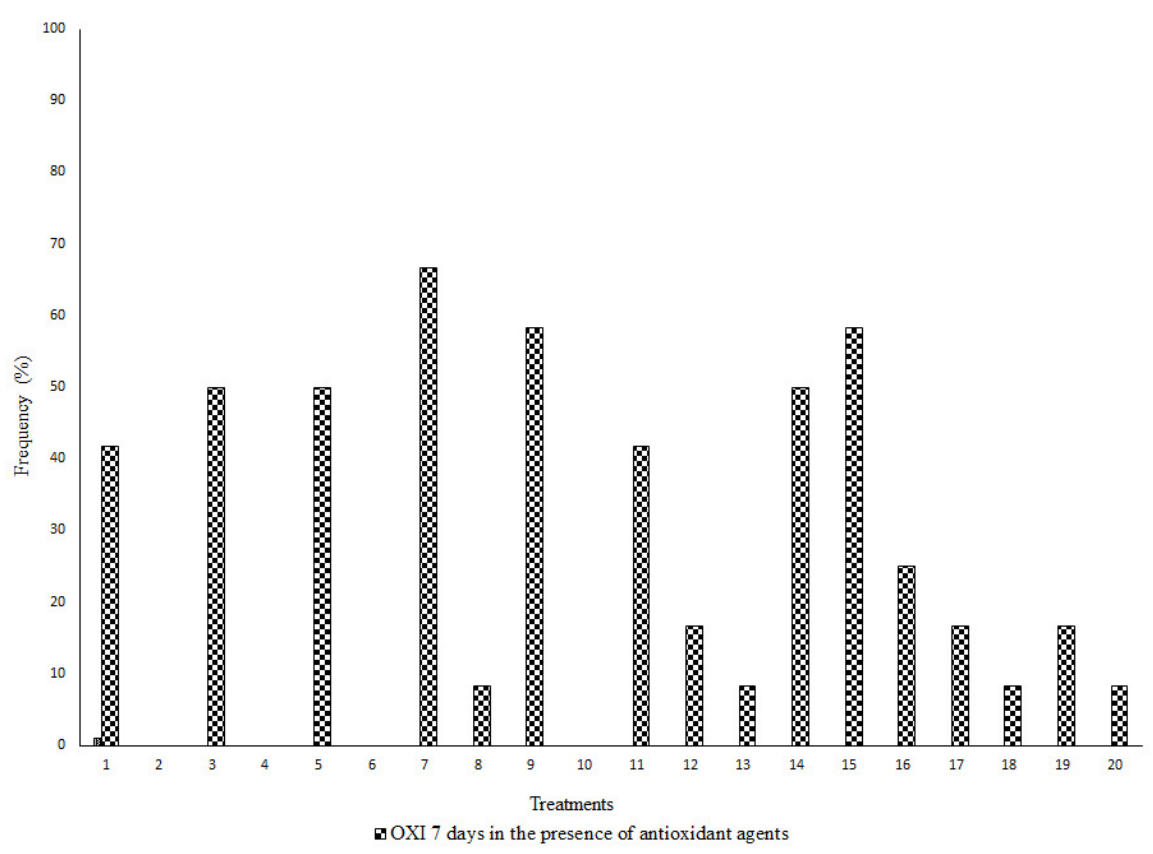

Figure 1. Frequency distribution (\%) of oxidation (OXI) seven days after in vitro inoculation of Eugenia pyriformis with and without the use of antioxidant agents. 


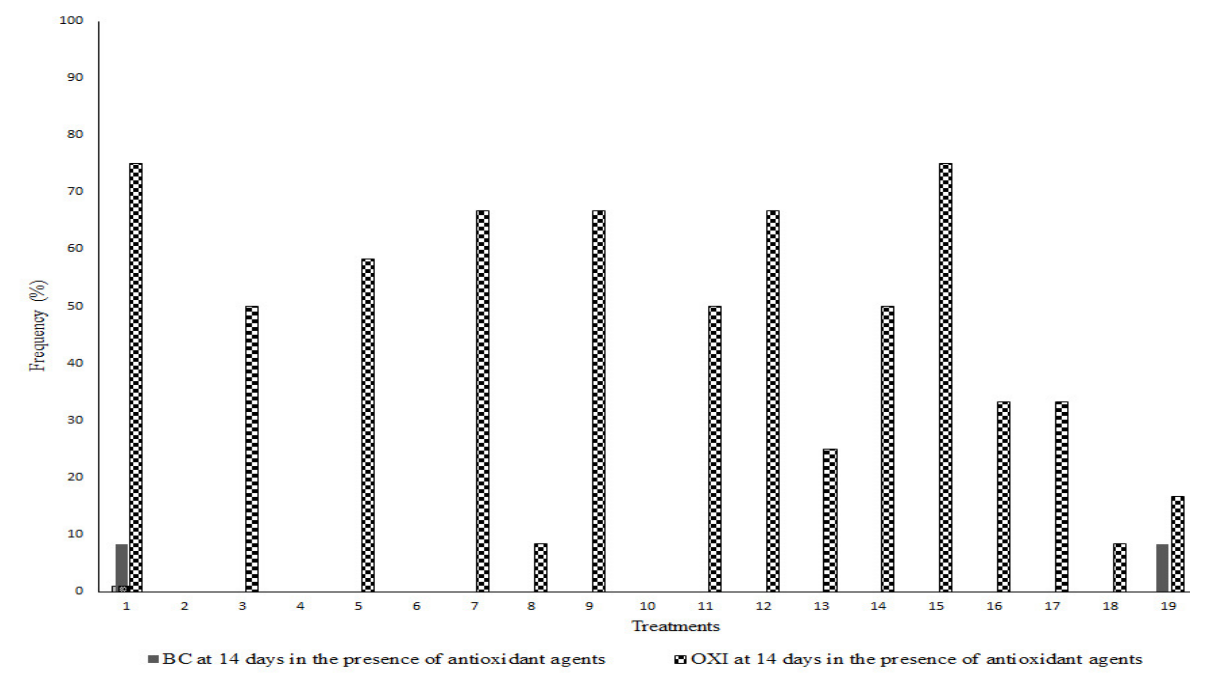

Figure 2. Frequency distribution (\%) of bacterial contamination (BC) and oxidation (OXI) 14 days after in vitro inoculation of Eugenia pyriformis with and without antioxidant agents.

Where oxidation was concerned, treatments T1, T3, T5, T7, T9, T11, T12, T14 and T15 did not confer satisfactory protection of the plant material 14 days after in vitro inoculation. This was based on the occurrence of phenol oxidation and darkening in $50 \%$ or more of the explants. This occurred mainly when the antioxidants were not in the presence of activated charcoal (Figure 2).
After 21 days of inoculation (Figure 3), bacterial colonies developed in treatments $\mathrm{T} 5$ and T19 (Figure 4). Conversely, the appearance of fungal mycelia (Figure 5) was observed in T13. This was despite no more than $8.3 \%$ of explants being contaminated.

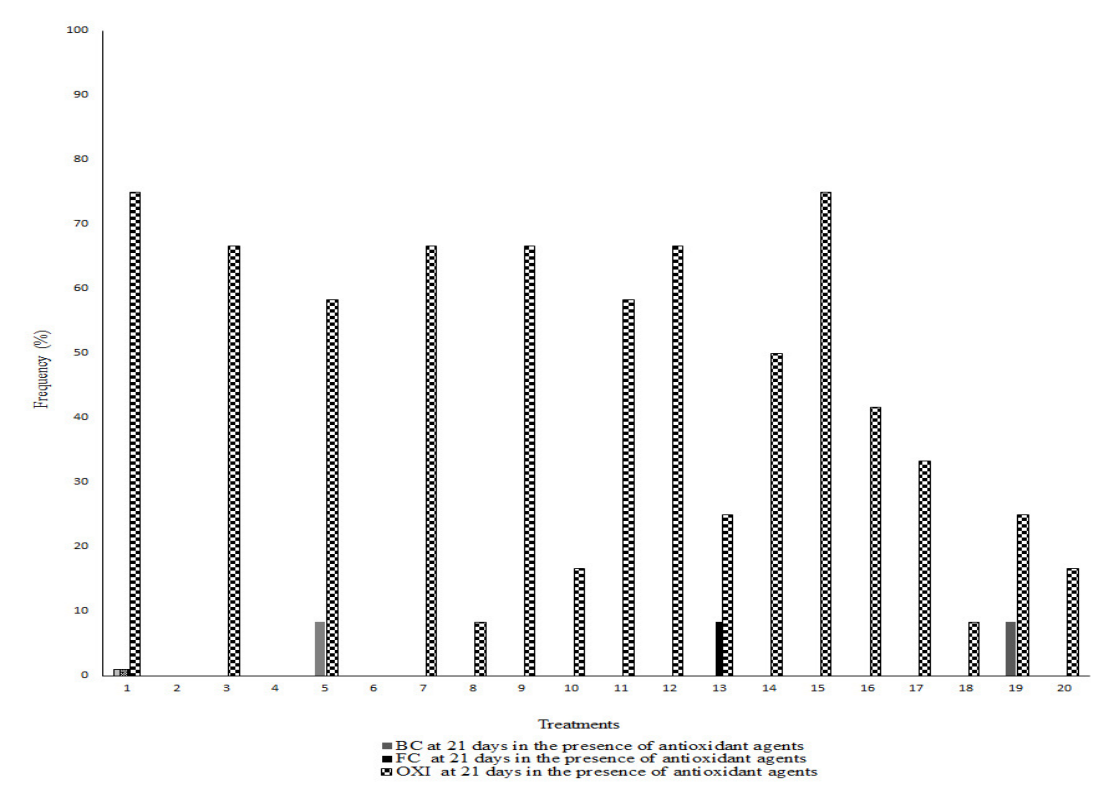

Figure 3. Frequency distribution (\%) of bacterial (BC) and fungal (FC) contaminations, and oxidation (OXI) after 21 days of in vitro inoculation of Eugenia pyriformis with and without antioxidant agents. 

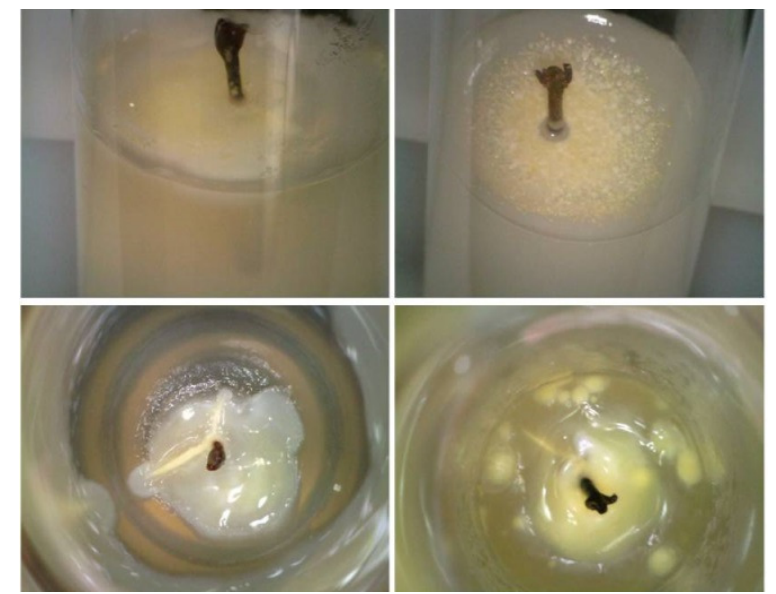

Figure 4. Bacterial contaminations of in vitro cultivations of Eugenia pyriformis.
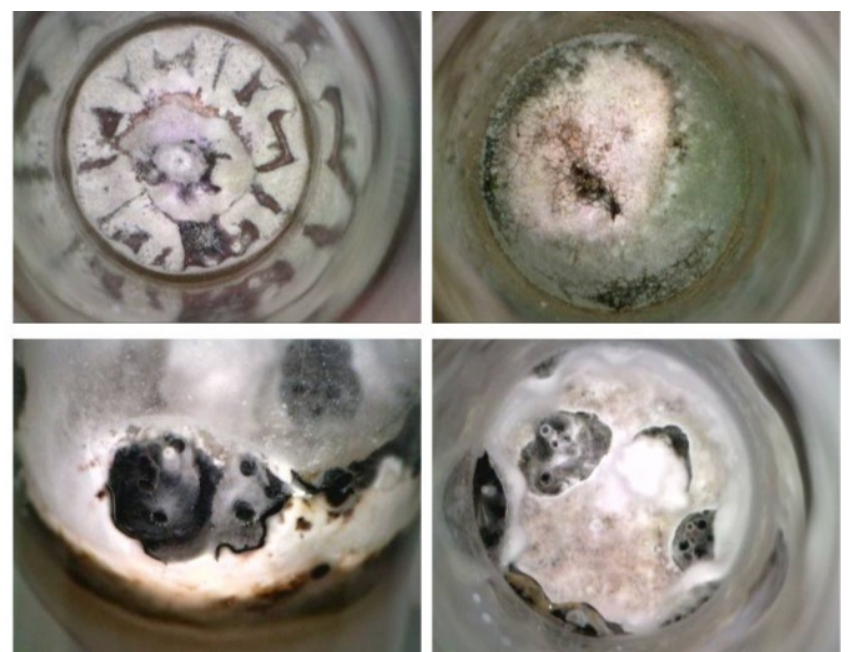

Figure 5. Fungal contaminations of in vitro cultivations of Eugenia pyriformis.

More than $50 \%$ of the explants in the treatments $\mathrm{T} 1, \mathrm{~T} 3, \mathrm{~T} 5, \mathrm{~T} 7, \mathrm{~T} 9, \mathrm{~T} 11, \mathrm{~T} 12, \mathrm{~T} 14$ and T15 exhibited oxidation 21 days after in vitro inoculation (Figure 3).

The formation of bacterial colonies and/or fungal mycelia near the explants was negligible 7 , 14 and 21 days after inoculation. This may have been due to the antimicrobial activity of the antioxidant agents tested (PVP, L-cysteine and activated charcoal) during micropropagation. Another explanation for the low frequency of bacterial contamination may be the result of the aseptic treatment of plants in the field. Both bactericides and fungicides were used prior to the inoculation, which may also have contributed to the protection of the plants following in vitro inoculation. This may have been due to the residual effects of those substances on the plants.

Even though the occurrence of microbial contamination was low in this study, it is important to control these microorganisms, as these contaminants can compete with the explants for the nutrients in the culture medium, releasing toxic metabolites that can lead to the death of the plant (PEREIRA et al., 2003). This creates obstacles for the tissue culture of plant species, especially ligneous plants (GOLLE et al., 2013).

In a similar study, Sousa et al. (2007) reported that supplementing culture medium with $0.1 \%$ activated charcoal $\left(1 \mathrm{~g} \mathrm{~L}^{-1}\right)$ was effective in reducing bacterial and fungal contaminations by $60 \%$ (without activated charcoal) to $20 \%$ (with activated charcoal) during the micropropagation of the orchid, Cattleya walkeriana. In addition, the use of ascorbic acid (150 mg L $\left.\mathrm{L}^{-1}\right)$, when used in conjunction with citric acid $\left(200 \mathrm{mg} \mathrm{L}^{-1}\right)$, helped to reduce bacterial contamination in guava buds, Psidium guajava L. (Myrtaceae) 72 hours after in vitro inoculation (CONCEPCIÓN et al., 2005).

Since oxidation was observed in all the time periods analyzed (Figure 6), the interaction between different types of antioxidants (PVP, L-cysteine and ascorbic acid), as well as their concentrations and activated charcoal, had a significant effect $(p<0.05)$ on the reduction of phenolic exudation and darkening of the explants 7 days after inoculation. 

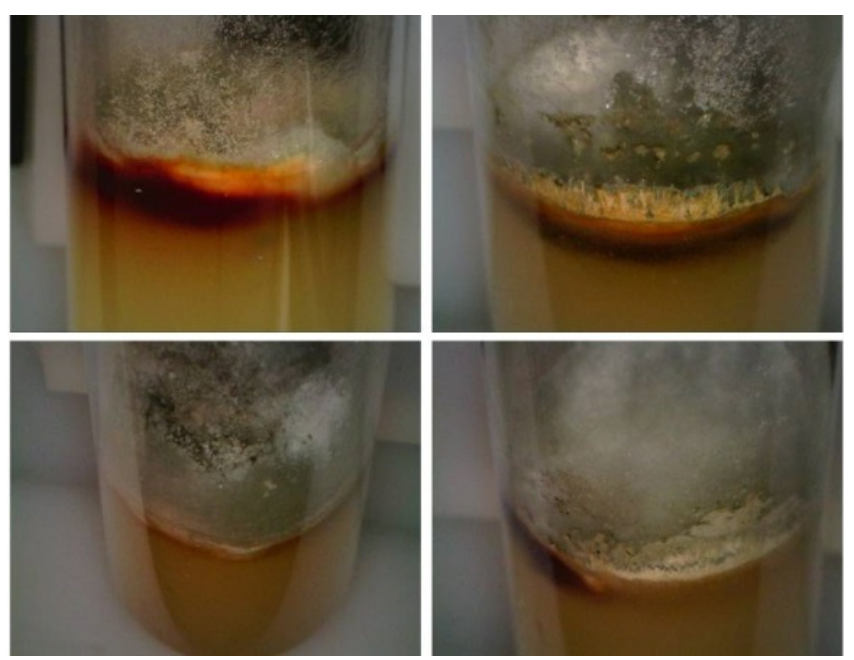

Figure 6. Oxidation in Eugenia pyriformis in vitro cultivation.

The lowest percentage of E. pyriformis oxidation resulted from the antioxidants L-cysteine or ascorbic acid used at a concentration of $300 \mathrm{mg}$ $\mathrm{L}^{-1}$ without the addition of activated charcoal, when compared to that of PVP. The use of PVP or ascorbic acid, when used at the same concentration, as well as $2 \mathrm{~g} \mathrm{~L}^{-1}$ activated charcoal, also decreased the oxidative process in uvaia more than the use of L-cysteine did (Table 1).

Table 1. Percentage of oxidation of Eugenia pyriformis explants treated with different types and concentrations of antioxidants, with and without activated charcoal, 7 days after in vitro inoculation.

\begin{tabular}{|c|c|c|c|c|c|c|}
\hline \multirow[t]{2}{*}{ Antioxidant } & \multicolumn{2}{|c|}{$\begin{array}{l}\text { Concentration } \\
100 \mathrm{mg} \mathrm{L}^{-1}\end{array}$} & \multicolumn{2}{|c|}{$\begin{array}{l}\text { Concentration } \\
200 \mathrm{mg} \mathrm{L}^{-1}\end{array}$} & \multicolumn{2}{|c|}{$\begin{array}{l}\text { Concentration } \\
300 \mathrm{~m} \mathrm{~L}^{-1}\end{array}$} \\
\hline & $\begin{array}{l}\text { Activated } \\
\text { charcoal } \\
0 \mathrm{~g} \mathrm{~L}^{-1}\end{array}$ & $\begin{array}{l}\text { Activated } \\
\text { charcoal } \\
2 \mathrm{~g} \mathrm{~L}^{-1}\end{array}$ & $\begin{array}{l}\text { Activated } \\
\text { charcoal } \\
0 \mathrm{~g} \mathrm{~L}^{-1}\end{array}$ & $\begin{array}{l}\text { Activated } \\
\text { charcoal } \\
2 \mathrm{~g} \mathrm{~L}^{-1}\end{array}$ & $\begin{array}{l}\text { Activated } \\
\text { charcoal } \\
0 \mathrm{~g} \mathrm{~L}^{-1}\end{array}$ & $\begin{array}{l}\text { Activated } \\
\text { charcoal } \\
2 \mathrm{~g} \mathrm{~L}^{-1}\end{array}$ \\
\hline PVP & $50.0 \mathrm{a}$ & $0.0 \mathrm{a}$ & $50.0 \mathrm{a}$ & $0.0 \mathrm{a}$ & $66.7 \mathrm{a}$ & $8.3 \mathrm{~b}$ \\
\hline L-cysteine & $58.3 \mathrm{a}$ & $0.0 \mathrm{a}$ & $41.7 \mathrm{a}$ & $16.7 \mathrm{a}$ & $8.3 \mathrm{~b}$ & $50.0 \mathrm{a}$ \\
\hline $\begin{array}{l}\text { Ascorbic } \\
\text { acid }\end{array}$ & $58.3 \mathrm{a}$ & $25.0 \mathrm{a}$ & $16.7 \mathrm{a}$ & $8.3 \mathrm{a}$ & $16.7 \mathrm{~b}$ & $8.3 \mathrm{~b}$ \\
\hline
\end{tabular}

Phenol oxidation, which is associated with the dark coloring of the explant, is another impediment to be overcome during the establishment of ligneous plants in vitro. According to Golle et al. (2012), the presence of oxidation in the explants, though undesirable, do not appear to hinder the establishment and development of the cultures in vitro. This was not confirmed in the present study because the oxidation compromised $E$. pyriformis micropropagation in a way that did not allow us to evaluate the development of the plants in vitro. The use of antioxidant agents is therefore justified, especially for the cultivation of Myrtaceae. This is due to the elevated release of phenolic compound exudates in the culture medium (AGUILAR et al., 2016).

Similarly, the following the development of an in vitro protocol for the guava tree, Aguilar et al.
(2016) reported that the best treatment with an antioxidant and disinfectant was obtained using $0.5 \%$ PVP, 5\% chlorine and 3 drops of tween 20. This ensured the survival of $90 \%$ of the explants. Likewise, the addition of $15 \mathrm{~mL} \mathrm{~L}^{-1}$ ascorbic acid to the MS culture medium was efficient in preventing oxidation in banana tree explants (Musa spp.). This helped to maintain the green color of the pseudostem, indicating that the quality of the plant material used as explant was preserved (ANICEZIO, 2012).

The interaction between antioxidants and their concentrations had a significant effect $(p<0.05)$ on explant oxidation 14 days after in vitro inoculation. The use of $200 \mathrm{mg} \mathrm{L}^{-1}$ ascorbic acid led to more than $50 \%$ reduction in the percentage of phenol oxidation over that observed when using Lcysteine (Table 2). 
Table 2. Percentage of oxidation of Eugenia pyriformis explants subjected to different types and concentrations of antioxidants 14 days following in vitro inoculation.

\begin{tabular}{llll}
\hline \multicolumn{4}{c}{ Concentrations } \\
\hline Antioxidant & $100 \mathrm{mg} \mathrm{L}^{-1}$ & $200 \mathrm{mg} \mathrm{L}^{-1}$ & $300 \mathrm{mg} \mathrm{L}^{-1}$ \\
\hline PVP & $8.3 \mathrm{a}$ & $29.2 \mathrm{ab}$ & $37.5 \mathrm{a}$ \\
L-cysteine & $16.7 \mathrm{a}$ & $58.3 \mathrm{a}$ & $37.5 \mathrm{a}$ \\
Ascorbic acid & $37.5 \mathrm{a}$ & $20.8 \mathrm{~b}$ & $16.7 \mathrm{a}$ \\
\hline
\end{tabular}

Means followed by the same letter in the column do not significantly differ between each other, according to Tukey's test $(p \leq 0.05)$.

With regard to the same period of time, there was a significant interaction $(p<0.05)$ between antioxidants and activated charcoal. The use of PVP, regardless of the concentration, when used in conjunction with $2 \mathrm{~g} \mathrm{~L}^{-1}$ activated charcoal, led to a reduction in phenolic exudation that was 13.8 times less that that caused by the use of L-cysteine (Table $3)$.

Table 3. Percentage of oxidation of Eugenia pyriformis explants subjected to different levels of activated charcoal and types of antioxidant, 14 days following in vitro inoculation.

\begin{tabular}{lll}
\hline & Activated charcoal & \\
\hline Antioxidant & $0 \mathrm{~g} \mathrm{~L}^{-1}$ & $2 \mathrm{~g} \mathrm{~L}^{-1}$ \\
\hline PVP & $47.2 \mathrm{a}$ & $2.8 \mathrm{~b}$ \\
L-cysteine & $36.1 \mathrm{a}$ & $38.9 \mathrm{a}$ \\
Ascorbic acid & $30.5 \mathrm{a}$ & $19.4 \mathrm{ab}$
\end{tabular}

Means followed by the same letter in the column do not significantly differ between each other, according to Tukey's test ( $p \leq 0.05)$.

Similarly, Costa et al. (2007) also reported that PVP and activated charcoal were agents capable of reducing phenol oxidation. The addition of $0.5 \mathrm{~g}$ $\mathrm{L}^{-1} \mathrm{PVP}$ or $3.0 \mathrm{~g} \mathrm{~L}^{-1}$ activated charcoal to the MS culture medium contributed to the lower percentage of oxidation of pepper-rosmarin (Lippia sidoides Cham.) in vitro, increasing survival rates of the explants, when compared to the controls (absence of antioxidants).
Twenty-one days after in vitro inoculation, there was a significant $(p<0.05)$ interaction between antioxidants and activated charcoal. It was concluded that the use of PVP, regardless of the concentrations used, and when used in with the presence of $2 \mathrm{~g} \mathrm{~L}^{-1}$ of activated charcoal, appeared to reduce the extent of oxidation in vitro more than L-cysteine did. As a result, there was $41.6 \%$ more oxidation in the explants when L-cysteine was used than in those in which PVP was used (Table 4).

Table 4. Percentage of oxidation of Eugenia pyriformis explants treated with different levels of activated charcoal and types of antioxidant 21 days after in vitro inoculation.

\begin{tabular}{lll}
\hline & Activated charcoal & \\
\hline Antioxidant & $0 \mathrm{~g} \mathrm{~L}^{-1}$ & $2 \mathrm{~g} \mathrm{~L}^{-1}$ \\
\hline PVP & $52.8 \mathrm{a}$ & $2.8 \mathrm{~b}$ \\
L-cysteine & $50.0 \mathrm{a}$ & $44.4 \mathrm{a}$ \\
Ascorbic acid & $33.3 \mathrm{a}$ & $22.2 \mathrm{ab}$ \\
\hline
\end{tabular}

Means followed by the same letter in the column do not significantly differ between each other, according to Tukey’s test ( $p \leq 0.05)$.

The use of PVP $\left(10 \mathrm{~g} \mathrm{~L}^{-1}\right.$ in semi-solid medium or $5 \mathrm{~g} \mathrm{~L}^{-1}$ in liquid medium) and activated charcoal $\left(250\right.$ or $500 \mathrm{mg} \mathrm{L}^{-1}$ in semi-solid culture medium) resulted in less explant oxidation of the forest species Terminalia amazonia (Gmel.) Excell. This was observed only in the upper and lower parts, with no color alteration of the culture medium, in addition to increased survival of the plant material established in vitro (MÉNDEZÁLVAREZ and ABDELNOUR-ESQUIVEL, 2014).
The results of PVP use are related to the properties of this polymer, which has the ability to absorb organic compounds using hydrogen molecules, such as phenols, thereby reducing or avoiding oxidation (CONCEPCIÓN et al., 2005).

Even though the use of antioxidant agents is not necessary for the control of microbial contaminants, its use is useful for minimizing oxidative processes, making the cultivation of $E$. pyriformis in vitro viable. 


\section{CONCLUSION}

With regard to bacterial and fungal contaminations, the in vitro cultivation of $E$. pyriformis can be performed without the use of antioxidant agents. However, PVP or ascorbic acid, at a concentration of $300 \mathrm{mg} \mathrm{L}^{-1}$, when used in conjunction with $2 \mathrm{~g} \mathrm{~L}^{-1}$ activated charcoal, is recommended for minimizing the effects of phenol oxidation.

\section{ACKNOWLEDGEMENTS}

We thank the $\mathrm{CNPq}$ for financially supporting the project and granting the first author a Junior Post-Doctoral research fellowship.

RESUMO: A uvaia Eugenia pyriformis é uma frutífera da família das mirtáceas cujas sementes apresentam longevidade curta e aspecto recalcitrante, fato que dificulta a propagação seminífera. A micropropagação surge como alternativa para obtenção de grande quantidade de mudas em curto período de tempo, por meio da utilização de qualquer parte da planta como explante. A elevada concentração de fenóis associados à composição química das mirtáceas e a presença de microrganismos no material vegetal ou no meio de cultura podem dificultar e/ou impossibilitar a propagação in vitro. Objetivou-se avaliar tipos e concentrações de antioxidantes no controle da contaminação microbiana e da oxidação fenólica in vitro de E. pyriformis. Utilizou-se o delineamento inteiramente casualizado em esquema fatorial 3 (antioxidantes - PVP, L-cisteína e ácido ascórbico) x 3 (concentrações - 100, 200 e 300 mg L L $^{-1}$ x 2 (carvão ativado - 0 e 2 $\left.\mathrm{g} \mathrm{L}^{-1}\right)+2$ adicionais (ausência de antioxidantes e de carvão ativado; ausência de antioxidantes com $2 \mathrm{~g} \mathrm{~L}^{-1}$ de carvão ativado), com três repetições constituídas por quatro plantas. Após sete, 14 e 21 dias do cultivo in vitro foram avaliadas a porcentagem de contaminação bacteriana, fúngica e de explantes oxidados. Conclui-se que o cultivo in vitro de $E$. pyriformis, em relação as contaminações bacterianas e fúngicas, pode ser efetuado sem a utilização de agentes antioxidantes. Entretanto, para reduzir a oxidação fenólica deve ser utilizado o PVP ou ácido ascórbico, ambos na concentração de $300 \mathrm{mg} \mathrm{L}^{-1}$, associados a $2 \mathrm{~g} \mathrm{~L}^{-1}$ de carvão ativado.

PALAVRAS-CHAVE: Ácido ascórbico. Carvão ativado. L-cisteína. Polivinilpirrolidona. Uvaia.

\section{REFERENCES}

AGUILAR, L. P.; ESPINO, H. S.; MONTERO, L. L. V.; SEGOVIA, C. P.; BENÍTEZ, S. F. Propagación in vitro de guayaba (Psidium guajava L.) a partir de segmentos nodales. Rev. Mex. Cienc. Agríc., v. 7, n. 2, p. 375-386, 2016.

ANICEZIO, L. C. Efeito de antioxidantes e descontaminantes no estabelecimento de explantes de bananeira (Musa spp) in vitro. Uniciências, v. 16, n. 1, p. 9-16, 2012.

BASSAN, J. S.; REINIGER, L. R. S.; ROCHA, B. H. G.; SEVERO, C. R. P.; FLÔRES, A. V. Oxidação fenólica, tipo de explante e meios de cultura no estabelecimento in vitro de canafístula (Peltophorum dubium (Spreng.) Taub.). Ci. Fl., v. 16, n. 4, p. 381-390, 2006. https://doi.org/10.5902/198050981919

CONCEPCIÓN, O.; NÁPOLES, L.; PÉREZ, A. T.; HERNÁNDEZ, M.; PERALTA, N.; TRUJILLO, R. Efecto de tres antioxidantes en el cultivo in vitro de ápices de guayaba (Psidium guajava L.). relación entre el origen del explante y el contenido de compuestos fenólicos. Cultivos Tropicales, v. 26, n. 1, p. 33-39, 2005.

COSTA, A. S.; ARRIGONI-BLANK, M. F.; BLANK, A. F.; MENDONÇA, A. B.; AMANCIO, V. F.; LEDO, A. S. Estabelecimento de alecrim-pimenta in vitro. Hortic. bras., v. 25, n. 1, p. 68-72, 2007. https://doi.org/10.1590/S0102-05362007000100013

GARCÍA-GONZÁLES, R.; QUIROZ, K.; CARRASCO, B.; CALIGARI, P. Plant tissue culture: Current status, opportunities and challenges. Cien. Inv. Agr., v. 37, n. 3, p. 5-30, 2010. https://doi.org/10.4067/S071816202010000300001

GOLLE, D. P.; REINIGER, L. R. S.; CURTI, A. R.; LEÓN, E. A. B. Estabelecimento e desenvolvimento in vitro de Eugenia involucrata DC.: influência do tipo de explante e do meio nutritivo. Ci. Fl., v. 22, n. 1, p. 207-214, 2012. https://doi.org/10.5902/198050985092 
GOLLE, D. P.; REINIGER, L. R. S.; BELLÉ, R. A.; CURTI, A. R. Desinfestação superficial de explantes isolados de ramos semilenhosos e herbáceos de Eugenia involucrata DC. (Myrtaceae). Cerne, v. 19, n. 1, p. 77-82, 2013. https://doi.org/10.1590/S0104-77602013000100010

HAMINIUK, C. W. I.; PLATA-OVIEDO, M. S. V.; MATTOS, G.; CARPES, S. T.; BRANCO, I. G.

Extraction and quantification of phenolic acids and flavonols from Eugenia pyriformis using different solvents. J Food Sci Technol, v. 51, n. 10, p. 2862-2866, 2014. https://doi.org/10.1007/s13197-012-0759-z

LAUKKANEN, H.; RAUTIAINEN, L.; TAULAVUORI, E.; HOHTOLA, A. Changes in cellular structures and enzymatic activities during browning of Scots pine callus derived from mature buds. Tree Physiol, v. 20, n. 7, p. 467-475, 2000. https://doi.org/10.1093/treephys/20.7.467

LEONE, G. F.; ALMEIDA, C. V.; ABREU-TARAZI, M. F.; BATAGIN-PIOTTO, K. D.; ARTIOLICOELHO, F. A.; ALMEIDA, M. Antibioticoterapia em microplantas de abacaxizeiro (Ananas comosus). Cienc. Rural, v. 46, n. 1, p. 89-94, 2016. https://doi.org/10.1590/0103-8478cr20130958

MAMANI, I.; AVERANGA, K.; ESPINOZA, B.; TERRAZAS, E. Establecimiento del sistema de generación in vitro de callos de Lupinus mutabilis Sweet (Tarwi) a partir de hipocótilos. Revista de Ciencias

Farmacéuticas y Bioquímicas, v. 2, n. 1, p. 27-37, 2014.

MARINHO, M. J. M.; ALBUQUERQUE, C. C.; MORAIS, M. B.; SOUZA, M. C. G.; SILVA, K. M. B. Estabelecimento de protocolo para micropropagação de Lippia gracilis Schauer. Rev. Bras. Pl. Med. v. 13, n. 2, p. 246-252, 2011. https://doi.org/10.1590/S1516-05722011000200019

MÉNDEZ-ÁLVAREZ, D.; ABDELNOUR-ESQUIVEL, A. Establecimiento in vitro de Terminalia amazonia (Gmel.) Excell. Revista Forestal Mesoamericana Kurú, v. 11, n. 27, p. 07-21, 2014.

MORAIS, T. P.; LUZ, J. M. Q.; SILVA, S. M.; RESENDE, R. F.; SILVA, A. S. Aplicações da cultura de tecidos em plantas medicinais. Rev. Bras. Pl. Med., v.14, n.1, p.110-121, 2012. https://doi.org/10.1590/S151605722012000100016

MURASHIGE, T.; SKOOG, F. A revised medium for rapid growth and bio-assays with tobacco tissue cultures. Physiol. Plant., v. 15, n. 3, p. 437-496, 1962. https://doi.org/10.1111/j.1399-3054.1962.tb08052.x

NASCIMENTO, A. C.; PAIVA, R.; NOGUEIRA, R. C.; PORTO, J. M. P.; NOGUEIRA, G. F.; SOARES, F. P. BAP E AIB no cultivo in vitro de Eugenia pyriformis Cambess. Rev. Acad. Ciênc. Agrár. Ambient., v. 6, n. 2, p. 223-228, 2008.

PEREIRA, J. E. S.; MATTOS, M. L. T.; FORTES, G. R. L. Identificação e controle com antibióticos de bactérias endofíticas contaminantes em explantes de batata micropropagados. Pesq. agropec. bras., v. 38, n. 7 , p. 827-834, 2003.

PINHAL, H. F.; ANASTÁCIO, M. R.; CARNEIRO, P. A. P.; SILVA, V. J.; MORAIS, T. P.; LUZ, J. M. Q. Aplicações da cultura de tecidos vegetais em fruteiras do Cerrado, Cienc. Rural, v. 41, n. 7, p. 1136-1142, 2011. https://doi.org/10.1590/S0103-84782011005000089

PLETSCH, M. Compostos naturais biologicamente ativos. Biotecnologia Cienc. Desenvolv., v.4, p.12-5, 1998.

R DEVELOPMENT CORE TEAM. R: a language and environment for statistical computing. Vienna, 2014. Disponível em: http://www.R-project.org. Acesso em: 1 jul. 2015.

RAMOS, S. L. F.; LOPES, M. T. G.; SAMPAIO, P. T. B.; CHAGAS, E. A.; PASQUAL, M.; SILVA, P. P. Tipo de explante e diferentes concentrações de sais em meio de cultura MS no estabelecimento in vitro de Aniba canelilla. Revista de Ciências Agrárias, v. 56, n. 4, p. 376-379, 2013. https://doi.org/10.4322/rca.2013.056 
RODRIGUES, F. A.; PENONI, E. S.; SOARES, J. D. R.; PASQUAL, M. Diferentes concentrações de sais do meio MS e BAP na multiplicação in vitro de Physalis peruviana L. Biosc. J., v. 29, n. 1, p. 77-82, 2013.

SARTOR; F. R.; ZANOTTI; R. F.; PÔSSA; K. F.; PILON; A. M.; FUKUSHIMA, C. H. Diferentes meios de cultura e antioxidantes no estabelecimento in vitro do jacarandá da Bahia. Biosc. J., v. 29, n. 2, p. 408-411, 2013.

SCALON, S. P. Q.; NEVES, E. M. S.; MASETO, T. E.; PEREIRA, Z. V. Sensibilidade à dessecação e ao armazenamento em sementes de Eugenia pyriformis Cambess. (Uvaia). Rev. Bras. Frutic., v. 34, n. 1, p. 269276, 2012. https://doi.org/10.1590/S0100-29452012000100036

SILVA, N. A.; RODRIGUES, E.; MERCADANTE, A. Z.; ROSSO, V. V. Phenolic compounds and carotenoids from four fruits native from the Brazilian Atlantic Forest. J. Agric. Food Chem. v. 62, n. 22, p. 5072-5084, 2014. https://doi.org/10.1021/jf501211p

SOUSA, G. C.; CLEMENTE, P. L.; ISAAC, V. L. R.; FARIA, S. P.; CAMPOS, M. R. C. Contaminação microbiana na propagação in vitro de Cattleya walkeriana e Schomburgkia crispa. Revista Brasileira de Biociências, 5 (supl. 1), p. 405-407, 2007.

WILLADINO, L.; SOUTO, N. F. C.; ULISSES, C.; PORTO, A. L. F.; CAMARA,T.; SILVA, M. M. A. Embryos and lateral buds culture of Tapeinochilos Ananassae (Hassk). K. Schum. International Journal of Sciences, v. 2, p. 19-25, 2013. 